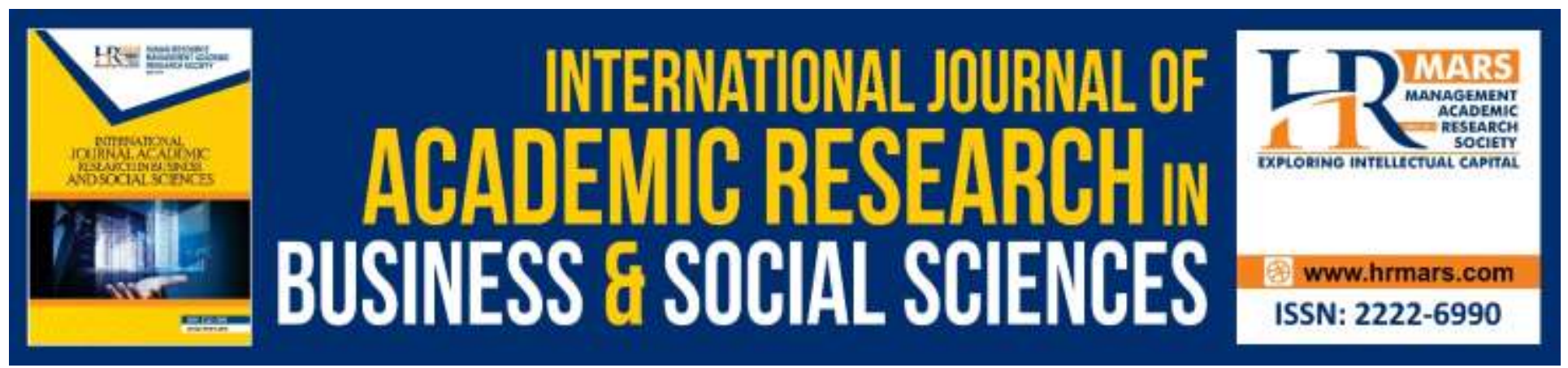

\title{
The Effectiveness of Emotional Intelligence Influence on Job Performance Moderated by Perceived Organizational Support from the Shift Employee Perspective
}

\author{
Hasnun Anip Bustaman, Ahmad Mudzfir Zubir, Wan Mohd Firdaus Wan \\ Mohamad, Mohammad Ikram Ramzi
}

To Link this Article: http://dx.doi.org/10.6007/IJARBSS/v10-i2/6943

DOI:10.6007/IJARBSS/v10-i2/6943

Received: 03 January 2020, Revised: 28 January 2020, Accepted: 02 February 2020

Published Online: 19 February 2020

In-Text Citation: (Bustaman et al., 2020)

To Cite this Article: Bustaman, H. A., Zubir, A. M., Mohamad, W. M. F. W., \& Ramzi, M. I. (2020). The Effectiveness of Emotional Intelligence Influence on Job Performance Moderated by Perceived Organizational Support from the Shift Employee Perspective. International Journal of Academic Research in Business and Social Sciences, 10(2), 452-464.

\section{Copyright: (C) 2020 The Author(s)}

Published by Human Resource Management Academic Research Society (www.hrmars.com)

This article is published under the Creative Commons Attribution (CC BY 4.0) license. Anyone may reproduce, distribute, translate and create derivative works of this article (for both commercial and non-commercial purposes), subject to full attribution to the original publication and authors. The full terms of this license may be seen

at: http://creativecommons.org/licences/by/4.0/legalcode

Vol. 10, No. 2, 2020, Pg. 452 - 464

http://hrmars.com/index.php/pages/detail/IJARBSS

JOURNAL HOMEPAGE

Full Terms \& Conditions of access and use can be found at http://hrmars.com/index.php/pages/detail/publication-ethics 


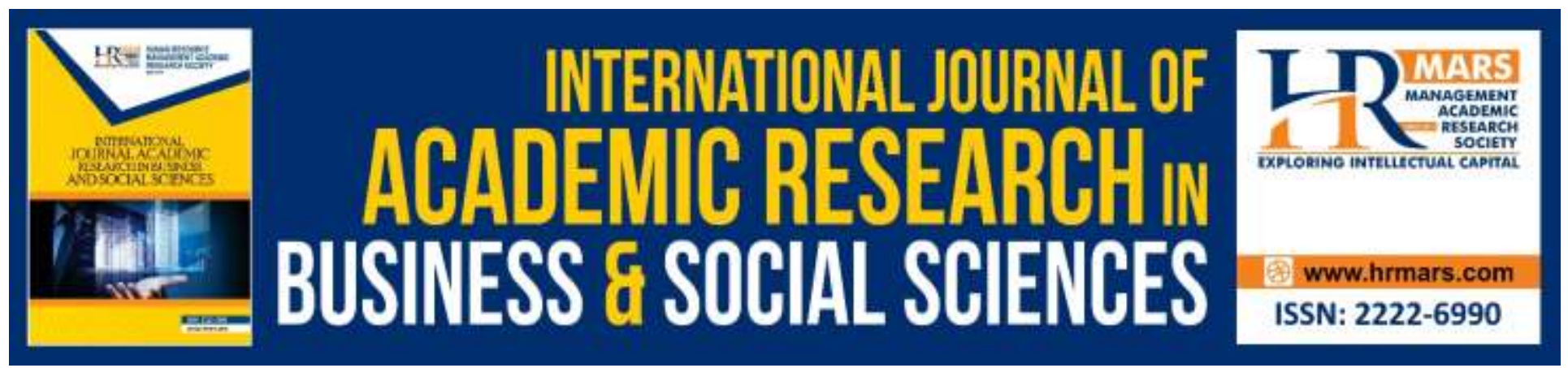

\title{
The Effectiveness of Emotional Intelligence Influence on Job Performance Moderated by Perceived Organizational Support from the Shift Employee Perspective
}

\author{
Hasnun Anip Bustaman, Ahmad Mudzfir Zubir, Wan Mohd Firdaus \\ Wan Mohamad, Mohammad Ikram Ramzi \\ Faculty of Business and Management, Universiti Teknologi MARA Cawangan Kelantan, Bukit Ilmu \\ 18500 Machang, Kelantan, Malaysia \\ Email: hasnun@gmail.com
}

\begin{abstract}
The purpose of this research is to investigate the moderating role of perceived organizational support in the relationship between emotional intelligence and job performance in the context of shift employee. Recently, a number of studies found that emotional intelligent is able to improve employee job performance in organization. However, the generalization does not include shift employees that have different types of issues and challenges; thus, this motivates the researchers to investigate the context. Data were gathered through self-administered questionnaire from 178 shift employees working in various Malaysia's government agencies and private agencies. The data were then analyzed to obtain the result. As hypothesized, job performance is significantly associated with emotional intelligence, and moderated by perceived organizational support. The relationship between emotional intelligence and job performance is stronger when perceived organizational support is high. The result conveys important information to organizations particularly in condition shift working hour. Emotional intelligence is well known for improving employee's job performance, with perceiving organizational support that contributes better job performance particularly for shift employees. The variables have to be simultaneously undertaken to harvest optimum outcome.
\end{abstract}

Keywords: Emotional Intelligence, Perceived Organizational Support, Job Performance, Signaling Theory, Shift Employee

\section{Introduction}

Nowadays, shift work matters to an organization to cater new market demand whether locally or globally. Locally, most people need to do their job during working hours especially those who are living in the big city. They normally deal with personal matters only after working hours which require 
organizations to extend operating hours longer than usual; thus, shift work was introduced. Globally, different time zone between countries requires organizations to operate 24 hours per day as to interact with each other to complete transaction immediately. Meaning to say, the shift work employment is inevitable and it is skyrocketing for organizations to interact with customers and between organizations. Unfortunately, many studies reported that this type of employment is regularly associated with employees' adverse effects (Loef et al., 2019).

Medical and scientific communities are persistently revealing that shift operation hours can expand the danger of specific issue and negatively affect the general prosperity of representatives (Bazazan, Rasoulzadeh, Dlanat, Safaiyan, \& Mombeini, 2019; LaDou, 1982). One of the negative impacts is employee's emotion. Employee's emotion is very important because it can influence employee's job performance (Nafukho, 2009). Employees' emotional dampens for a reason such as they are unsatisfied with devastation of normal routine day. Most of them complain about their day-off which is different than normal rest day. They cannot spend time with their family as spouse is at work and children are at school while they are at day-off. They seem alone on the day-off without family and friends that causes detrimental of family and friend relationship (Fitzpatrick, While, \& Roberts, 1999). The situation contributes to detrimental of emotion and finally affects their job performance (Welikala \& Dayarathna, 2015).

Scholars are aware the adverse effects from shift work to employee's performance since long time ago (Ferri et al., 2016; Fitzpatrick et al., 1999; LaDou, 1982; Mishra, 2012); however, paucity study has confined to mitigate the adverse effect. Therefore, our study investigates the effectiveness of emotional intelligence to mitigate the adverse effect of shift work which influences job performance and moderated by perceived organizational support from shift employee perspective. Mc Evoy (2006) conducted a research in petroleum industry and found a definitive relationship between emotional intelligence competencies and performance at work. The scholar found that emotional intelligence competencies accounted for $44 \%$ of overall work performance, cognitive ability only accounted for $19 \%$ while skills and knowledge accounted for $38 \%$. Meaning that, emotional intelligent is a significant variable in contributing towards employees' good performance. As the most effective agent to job performance, this study predicts that the variable mitigates the adverse impact of shift work which improves employees' job performance. On top of that, another form of relationship is also being considered to boost the relationship between emotional intelligence and job performance in the shift employee perspective.

\section{Literature}

\section{Emotional Intelligence}

The roots of emotional intelligence can be traced back to the work of Charles Darwin and his belief that emotional expression has a vital role in survival and adaptation. Howard Mc Evoy (2006) built on these beliefs and introduced the idea of multiple intelligences, including interpersonal intelligence, the capability to understand other people's desires, intentions and motivations, and intrapersonal intelligence which is the ability to understand one's own feelings, motivations and fears. 
INTERNATIONAL JOURNAL OF ACADEMIC RESEARCH IN BUSINESS AND SOCIAL SCIENCES Vol. 10, No. 2, Feb, 2020, E-ISSN: 2222-6990 @ 2020 HRMARS

Even though the term "emotional intelligence" had been around for some time as it was coined in 1966 by Leuner, it was not until 1990 that a definition and comprehensive framework for this concept was given. The concept is defined as "the ability to monitor one's own and other's feelings and emotions, to discriminate among them, and use this information to guide one's thinking and actions" (Cichy, Kim, \& Cha, 2009).

Many studies have attempted to prove that emotional intelligence is a good predictor of job performance. Result has shown high achiever recruiters significantly higher emotional intelligent compared to low performers, a study conducted on 1,171 U.S. air force recruiters (Nafukho, 2009). In another study, the performance indicators for combat soldiers are significantly different to performance indicators used in high technology and capital intensive environment such as the petroleum industry in which the study found a definitive relationship between emotional intelligence competencies and performance at work (Mc Evoy, 2006). These are similar results found from different research and types of work performance that make us posit a significant positive relationship between emotional intelligence and employees' performance in the shift employee perspective.

Hypothesis 1: There is a significant relationship between emotional intelligence and job performance among the shift workers.

Based on Salovey and Mayer's (1990) work and Goleman (1995) who popularized the El concept applied to workplace settings, emotional intelligence model consists of four general abilities: selfawareness, self-management, social awareness, and relationship management (Goleman, 1995, 1998).

Specifically, sub-hypotheses linked to $\mathrm{H} 1$ are:

Hypothesis 1a: There is a significant relationship between self-awareness and job performance towards shift work among employees at UTC Kelantan

Hypothesis 1b: There is a significant relationship between self-regulation and job performance towards shift work among employees at UTC Kelantan

Hypothesis 1c: There is a significant relationship between self-motivation and job performance towards shift work among employees at UTC Kelantan

Hypothesis $1 \mathbf{d}$ : There is a significant relationship between social skills and job performance towards among employees at UTC Kelantan.

\section{Moderation Impact of Perceived Organizational Support}

Maul (2012) conducted a study on a group of 69 students who had part-time jobs, with job performance being rated by their supervisors. Their results demonstrated that emotional intelligence significantly predicted job performance after controlling for cognitive ability. However, when they analyzed the results which controlled for conscientiousness, emotional intelligence did not 
INTERNATIONAL JOURNAL OF ACADEMIC RESEARCH IN BUSINESS AND SOCIAL SCIENCES Vol. 10, No. 2, Feb, 2020, E-ISSN: 2222-6990 @ 2020 HRMARS

significantly predict job performance. These results indicate that while emotional intelligence plays a role in job performance, there are other factors such as personality traits that affect a person's ability to perform at work. Mc Evoy (2006) also found that emotional intelligence alone was not a strong predictor of individual performance, but the presence of both emotional intelligence and conscientiousness demonstrated a strong positive relationship with individual performance.

In this study, we insist that perceive organizational support is able to contribute some effect to the relationship between emotional intelligence and job performance as based from signaling theory. Theoretically, perceived organizational support signals that the organization cares about employees (Grover \& Crooker, 1995; Spence, 1973) and such arrangements extend more control to employees facilitating their ability to meet work and non-work demands. According to signaling theory, shift employees interpret observable information conveyed by an organization as a signal of less observable characteristics (Spence, 1973). In the context of our study, shift employees infer that the extent to which an organization perceived support to them is based on the types of policies offered (Casper \& Harris, 2008; Grover \& Crooker, 1995). We posit that better organization policy for shift worker contributes to strengthening the relationship between emotional intelligence and job performance. Shift worker has done extra affords for organizational survival and improved organizational service. Thus, it is appropriate for them to receive better treatment from organization. The privileges have to be translated into organizational policy and perceived as support from the organization so that they can perform excellently in their job.

Hypothesis 2: The positive relationship between emotional intelligence and job performance will be stronger when perceived organizational support is high.

\section{Methodology}

A total of 178 shift workers participated in our study. Their demographics are as follows: 65.7 percent female; 82 percent Malay, 15 percent Chinese and 3 percent Indian. Participants who aged between 20 years old to 30 years old were 40 percent while 31 years old to 40 years old was 29 percent and 41 years old and above was 31 percent. Most of our respondents were married with 85 percent and the rest consists of single and divorced with 9 percent and 6 percent respectively. Lastly, we look at the income of the participants which was divided into three groups: below RM2000, RM2001 to RM 4000, and RM 4001 and above. Most of our participants had an income between RM2001 to RM4000 which represented 60 percent of total participants and 24 percent and 16 percent were those having an income of below RM2000 and above RM4000 respectively. It is important to note here that our participants were 100 percent of those who are working in the shift system.

\section{Design and Procedure}

Our study collected information from participants by using purposive sampling. The technique has been adhered for study conform to a specific criterion of participant which is shift workers (Sekaran \& Bougie, 2010). Other than that, our study does not have the list name of workers involved with shift work; however, we are clear on the exact location to distribute the questionnaire. The location is at UTC Kelantan. There are 12 federal agencies, 9 state agencies, 6 statutory body agencies and 14 private companies. The operation time for UTC Kelantan is based on shift. The running time of UTC is 
INTERNATIONAL JOURNAL OF ACADEMIC RESEARCH IN BUSINESS AND SOCIAL SCIENCES Vol. 10, No. 2, Feb, 2020, E-ISSN: 2222-6990 @ 2020 HRMARS

morning, noon and evening, and it is also opened 7 days per week except in public holiday. The participants answered the questionnaire while they were at the organization. We wanted the participants to evaluate our questionnaire while they are working to feel the working environment while answering the questionnaire. The time taken to complete the questionnaire was between 20 minutes to 30 minutes. After completed, the questionnaire was given back to us immediately.

\section{Measures}

Emotional Intelligence: All participants gave their responses based on sixteen items of emotional intelligence scale, and the scale was generated from Wong and Law (2002). The sample question of $\mathrm{El}$ is "I have a good sense of why I have certain feelings most of the time". The items were rated on a scale ranging from 1 = "Strongly disagree" to 7 = "Strongly agree"). Meanwhile, the Cronbach's Alpha was reported (.78) (Goleman and Cherniss, 2001).

Perceived Organizational Support: We used Rhoades and Eisenberger's (2002) measurement for the survey of perceived organizational support (POS). The measurement emphasizing two important perceptions are the extent employee perceived that organization values their contribution and cares about their well-being. This version of POS contains 8 of the 36 items that loaded highly on the main POS factors reported in the scales source of article by Eisenberger, Cummings, Armeli, and Lynch (1997) which was widely applied in a variety of organizations (Rhoades \& Eisenberger, 2002). The sample of POS questionnaire is "The organization values my contribution to its well-being". The items were rated on a scale ranging from 1 = "Strongly disagree" to 7 = "Strongly agree").

Job Performance: The measurement scale for job performance adopted from Day and Carroll (2004) whereby the scale was modified from Settoon, Bennett, and Liden (1996). The items were rated on a scale ranging from 1 = "Strongly disagree" to $7=$ "Strongly agree"). The sample of the JP questionnaire is "How do you rate yourself in terms of your performance potential among co-workers in your company?"

\section{Data Analysis and Result}

Our study tested the data using SmartPLS 3.0. Adhering to the principles and procedurals of the tools is essential in producing a reliable result; thus, we decided to follow testing procedures as suggested by Hair, Sarstedt, Hopkins, and Kuppelwieser (2014). 
INTERNATIONAL JOURNAL OF ACADEMIC RESEARCH IN BUSINESS AND SOCIAL SCIENCES

Vol. 10, No. 2, Feb, 2020, E-ISSN: 2222-6990 @ 2020 HRMARS

Table 1: Correlations, means, and standard deviations of study variables

\begin{tabular}{|c|c|c|c|c|c|c|c|c|c|c|}
\hline No. & Variables & Mean & SD & 1 & 2 & 3 & 4 & 5 & 6 & 7 \\
\hline 1. & $\begin{array}{l}\text { Self- } \\
\text { awareness }\end{array}$ & 5.8274 & 67119 & & & & & & & \\
\hline 2. & $\begin{array}{l}\text { Self- } \\
\text { regulation }\end{array}$ & 5.8871 & .71145 & $.934^{* *}$ & & & & & & \\
\hline 3. & $\begin{array}{l}\text { Self- } \\
\text { motivation }\end{array}$ & 5.5390 & .72226 & $.879^{* *}$ & $.789^{* *}$ & & & & & \\
\hline 4. & Social skill & 6.1448 & .81325 & $.877^{* *}$ & $.734^{* *}$ & $.712^{* *}$ & & & & \\
\hline 5. & $\begin{array}{l}\text { Job } \\
\text { Performance }\end{array}$ & 5.8847 & .76536 & $.915^{* *}$ & $.739^{* *}$ & $.756^{* *}$ & $.767^{* *}$ & & & \\
\hline 6. & $\begin{array}{l}\text { Organizational } \\
\text { support }\end{array}$ & 5.8432 & .77132 & $.754^{* *}$ & $.639^{* *}$ & $.684^{* *}$ & $.666^{* *}$ & $.663^{* *}$ & & \\
\hline
\end{tabular}

\section{Measurement Model: Assessment of CFA}

Firstly, our study identified whether each study construct is reflective or formative measurement. The identification is important because each type requires different measurement. All constructs indicated reflective characteristic; thus, internal consistency reliability, indicator reliability, convergent validity and discriminant validity were calculated in our measurement model.

\section{Internal Consistency Reliability}

Chin (2010) proposed to refer to composite reliability by using PLS Graph to assess internal consistency. This study composite reliabilities (CR) ranged from 0.888 to 0.955 (see Table 2). The recommended cut-off is 0.70 , meaning that this study internal consistency and all constructs were within accepted limits and reliable (Chin, 2010; Hair et al., 2014)

\section{Factor Loading}

The intent to assess the burden of factors is to evaluate the extent of an indication or a set of indicators is consistent with what it intends to measure (Urbach \& Ahlemann, 2010). An examination of the factor loadings showed that factor loadings ranged from 0.728 to 0.919 , except for three items (reg3, reg4 and mot4), which exceeded the recommended thresholds of 0.708 (Chin, 2010) as shown in Table 2. Although the items SR3 (0.688), SR4 (0.693) and SS4 (0.699) were below than the thresholds, we weighed the average variance extracted (AVE) scores before any further action was executed. Our study's AVEs for self-regulation and self-motivation were 0.569 and 0.723 respectively. Loading values that equal and greater than 0.5 are acceptable, and if the summation of loadings result has high loading scores, it contributes to AVE scores of greater than 0.5 (Byrne, 2016). The conclusion is that those items (SR3, SR4 and SS4) are remained in respective constructs that are self-regulation and self-motivation as the items contributed to AVE scores of greater than 0.5 (see Table 2).

\section{Convergent Validity}

This type of measurement showed the level of study items converge in presenting the underlying construct that are purported to measure (Chin, 2010). The type of validity can be considered as 
INTERNATIONAL JOURNAL OF ACADEMIC RESEARCH IN BUSINESS AND SOCIAL SCIENCES Vol. 10, No. 2, Feb, 2020, E-ISSN: 2222-6990 @ 2020 HRMARS

satisfactory when the condition of AVE 0.5 or greater than that. This study recoded the AVE ranged from 0.569 to 0.772 (see Table 2), indicates that the construct explained more than half of the variance of its indicators (Chin, 2010). In additional, factor loading indicated narrow range between each construct (see Table 2), which suggested that the items converged in estimating the underlying construct (Chin, 2010).

Table 2: Factor Loadings, CR and AVE

\begin{tabular}{|c|c|c|c|c|c|c|}
\hline Latent Variables & Items & Factor Loading & Cronbach Alpha & rho & $\mathrm{CR}$ & AVE \\
\hline \multirow[t]{4}{*}{ Self-awareness } & SA1 & 0.861 & 0.921 & 0.932 & 0.938 & 0.753 \\
\hline & SA2 & 0.884 & & & & \\
\hline & SA3 & 0.869 & & & & \\
\hline & SA4 & 0.859 & & & & \\
\hline \multirow[t]{4}{*}{ Self-regulation } & SR1 & 0.789 & 0.877 & 0.878 & 0.888 & 0.569 \\
\hline & SR2 & 0.732 & & & & \\
\hline & SR3 & 0.688 & & & & \\
\hline & SR4 & 0.693 & & & & \\
\hline \multirow[t]{4}{*}{ Self-motivation } & SM1 & 0.842 & 0.878 & 0.877 & 0.909 & 0.713 \\
\hline & SM2 & 0.839 & & & & \\
\hline & SM3 & 0.870 & & & & \\
\hline & SM4 & 0.831 & & & & \\
\hline \multirow[t]{4}{*}{ Social skill } & SS1 & 0.869 & 0.871 & 0.884 & 0.908 & 0.723 \\
\hline & SS2 & 0.919 & & & & \\
\hline & SS3 & 0.899 & & & & \\
\hline & SS4 & 0.699 & & & & \\
\hline \multirow[t]{4}{*}{ Job performance } & JP1 & 0.831 & 0.889 & 0.911 & 0.925 & 0.711 \\
\hline & $\mathrm{JP} 2$ & 0.878 & & & & \\
\hline & JP3 & 0.880 & & & & \\
\hline & JP4 & 0.853 & & & & \\
\hline \multirow[t]{8}{*}{ Organizational support } & POS1 & 0.850 & 0.932 & 0.931 & 0.955 & 0.772 \\
\hline & POS2 & 0.888 & & & & \\
\hline & POS3 & 0.889 & & & & \\
\hline & POS4 & 0.890 & & & & \\
\hline & POS5 & 0.860 & & & & \\
\hline & POS6 & 0.888 & & & & \\
\hline & POS7 & 0.896 & & & & \\
\hline & POS8 & 0.839 & & & & \\
\hline
\end{tabular}

\section{Structural Model}

To validate our proposed hypotheses, we assess the path coefficient between two latent variables. The suggested value is at least 0.1 to account for some certain impact within the model (Hair et al., 2014). Base on the analysis, the hypotheses were significant at least at the level of 0.05 with positive sign direction while the path coefficient value $(\beta)$ ranging from 0.127 to 0.32 . Our study result showed that all proposed hypotheses were supported (see Table 3). 
INTERNATIONAL JOURNAL OF ACADEMIC RESEARCH IN BUSINESS AND SOCIAL SCIENCES

Vol. 10, No. 2, Feb, 2020, E-ISSN: 2222-6990 @ 2020 HRMARS

Based on the analysis, it showed that job performance was directly influenced by self-awareness $(\beta=0.127, t=1.700, p<0.05)$. As a result, hypothesis $\mathrm{H} 1$ and hypothesis $\mathrm{H} 1 \mathrm{a}$ were supported. Meanwhile, from the table, self-regulation, self-motivation, social skill, job of each independent variable recorded $(\beta=0.229, t=3.201, p<0.01),(\beta=0.170, t=2.301, p<0.05)$ and $(\beta=0.321, t=3.699$, $p<0.01$ ) respectively. This means that job performance was influenced by all independent variables; thus, $\mathrm{H} 1 \mathrm{~b}, \mathrm{H} 1 \mathrm{c}$ and $\mathrm{H} 1 \mathrm{~d}$ were supported.

Table 3: Structural Analysis Model Results

\begin{tabular}{|c|c|c|c|c|c|c|c|c|c|c|}
\hline $\begin{array}{l}\text { Hypothese } \\
\mathrm{S}\end{array}$ & $\begin{array}{l}\text { Std } \\
\text { Beta }\end{array}$ & $\begin{array}{l}\text { Std } \\
\text { Error }\end{array}$ & t-value & $\begin{array}{l}\text { Decisio } \\
\mathrm{n}\end{array}$ & LL & UL & $\mathrm{R}^{2}$ & $f^{2}$ & $\mathrm{Q}^{2}$ & $q^{2}$ \\
\hline \multirow[t]{2}{*}{$\mathrm{H} 1 \mathrm{a}$} & 0.127 & 0.069 & $1.700 *$ & Supp & 0.00 & 0.22 & 0.55 & 0.00 & 0.40 & 0.00 \\
\hline & & & & & 6 & 0 & 9 & 8 & 1 & 3 \\
\hline \multirow[t]{2}{*}{$\mathrm{H} 1 \mathrm{~b}$} & 0.229 & 0.073 & $3.201^{*}$ & Supp & 0.11 & 0.35 & & 0.04 & & 0.02 \\
\hline & & & $*$ & & 1 & 5 & & 1 & & 1 \\
\hline \multirow[t]{2}{*}{$\mathrm{H} 1 \mathrm{c}$} & 0.170 & 0.075 & $2.301^{*}$ & Supp & 0.03 & 0.29 & & 0.01 & & 0.00 \\
\hline & & & & & 9 & 0 & & 9 & & 9 \\
\hline \multirow[t]{2}{*}{$\mathrm{H} 1 \mathrm{~d}$} & 0.321 & 0.084 & $3.699 *$ & Supp & 0.16 & 0.45 & & 0.07 & & 0.02 \\
\hline & & & $*$ & & 9 & 1 & & 1 & & 9 \\
\hline \multicolumn{11}{|c|}{ Note: ${ }^{* *} p<0.001$ and ${ }^{*} p<0.005$} \\
\hline
\end{tabular}

\section{Moderating Analysis}

Using SmartPLS for analyzing the moderator effect can be tested through three (3) different methods. The selection of the right method is counted to have accurate result and interpretation. The method was divided into three types which were product indictor approach, two stage approach and orthogonalzing approach. As for our study, the second approach was employed in view that our moderator is continued variable compound and the approach yields the most accurate estimate of the single effects and it has higher statistical power test (Type 1 and Type 2 error) when compared to the other two approaches.

The changing of the $\mathrm{R}^{2}$ is an important matter in analyzing the moderation impact. Our study $\mathrm{R}^{2}$ in the main effect model is 0.294 while the interaction effect model recorded $R^{2}(0.309)$. The change is 0.015 which indicates that with the additional of one interaction term, the $\mathrm{R}^{2}$ has changed about $1.5 \%$ (additional variance). To interpret the magnificent of change, we refer to $f^{2}$ and following the guideline given by Kenny (2016), our $f^{2}$ is 0.0190 which indicates medium effect sizes as suggested. Next, we interpret the interaction effects in significant or not perspective.

Table 4: Results of the moderator analysis using two stage approach.

\begin{tabular}{lllll}
\hline \hline Hypotheses & Std Beta & Std Error & T Statistics & Decision \\
\hline $\mathrm{H} 2$ & 0.631 & 0.042 & $7.686^{* *}$ & Supported \\
\hline \hline
\end{tabular}

As we can see in Table 4, the interaction between emotional intelligence and perceived organizational support is positive. Thus, we can say that the positive relationship between emotional intelligence 
INTERNATIONAL JOURNAL OF ACADEMIC RESEARCH IN BUSINESS AND SOCIAL SCIENCES Vol. 10, No. 2, Feb, 2020, E-ISSN: 2222-6990 @ 2020 HRMARS

and job performance would be stronger when perceived organizational support is higher. To have a clearer effect of perceived organizational support, we draw the interaction plot as in figure 1.

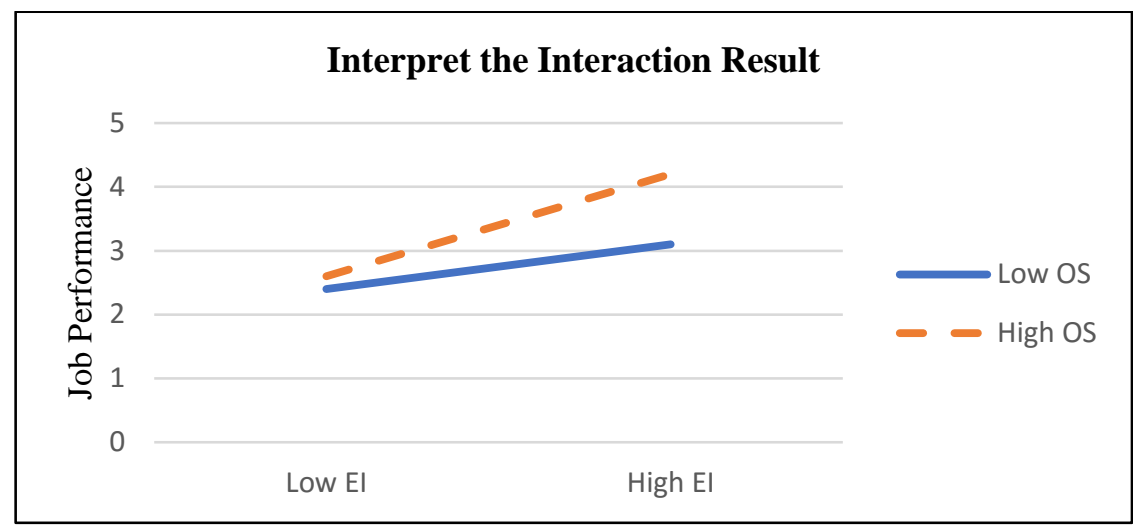

Figure 1: Interaction Plot between Emotional Intelligence, Perceived Organizational Support and Job Performance

The interpretation of the interaction plot is to look at the gradient of the slopes. As can be seen in figure 1, the line labelled for high perceived organizational support has a steeper gradient compared to low perceived organizational support, indicating that the positive relationship is stronger when perceived organizational support is high. Thus, our hypothesis is supported.

\section{Discussion}

To recap, our study's motivation is to explore emotional intelligence effect to employees' job performance particularly from the shift employees while they perceive organizational support. Literature showed that emotional intelligence has positive significant effect to job performance from the non-shift employee (Shooshtarian, Ameli, \& Aminilari, 2013). On top of that, this study posits that perceived organizational support is a significant moderator to stronger the relationship in the context of shift employee which is derived from signaling theory.

There are four dimensions of emotional intelligence which show positive significant relationship to job performance and it is in tandem with previous studies. Social skill dimension recorded the highest contribution which means employees with extrovert personality are most suitable for shift work. People with personality will respect others, have mutual regard, commitment, openness, tolerance, empathy, negotiation, communication etc. They mix around with colleagues and feel comfortable at workplace, which make them focus to work rather than their family. The result is consistent with the study by Mohamad and Jais (2016) which strengthens our finding.

In the flip side, self-motivation is the lowest contribution because the dimension is generated from the other dimensions. Less focus should be embarked on self-motivation compared to the other dimensions. Organization should emphasize on social skill and self-regulation in harvesting the positive outcome from emotional intelligence. However, that is not sufficient to face the challenges and issues from the shift working conditions by focusing on the inside individual employee alone. 
Therefore, our study proposed that organizational support as an additive variable to achieve higher effect to job performance, as based on signaling theory perspective.

Positive emotional such as emotional intelligence support by perceived organizational support strengthens employees' job performance. This conveys information that the individual role and organizational role contribute significant effect to employees' job performance. We believe that individual emotional is subjected to change according to environmental supportive. At an extent, organizational environment will influence individual including their emotional. Many studies have proven that personality might change according to organizational environment; however, scarce study has zoomed in individual emotional. Our study proves that individual emotional also changes and this is impacted by organizational condition which is the contribution to the theoretical and managerial perspectives. Moving on, the next part discusses theoretical and managerial implications of this study.

\section{Limitation and Future Research Direction}

Throughout our study, we found some school of thought has declared that emotional intelligence component consists of more than just four variables; however, our study only focuses on selfregulation, self-awareness, self-motivation and social skills. Thus, future study might explore on the other components to extend the finding and propose other contributions. Other than that, we thought that it would be more interesting to conduct a study by using the mixed method model or hybrid model to study about emotional intelligence and job performance. The method seems to be gaining popularity and most importantly, it may produce better findings.

\section{Conclusion}

Emotional intelligence impacts job performance which is strengthened by perceived organizational support that deciphers important massage in managing shift employees. Emotional intelligence is well-known for improving employees' job performance, but perceived organizational support has empirically proven to contribute better effect in the case of the shift employee. The variables, which are improving employee emotional intelligence and showing organizational support, have to be executed simultaneously to harvest the optimum outcome.

\section{References}

Bazazan, A., Rasoulzadeh, Y., Dlanat, I., Safaiyan, A., \& Mombeini, Z. (2019). Occupational fatigue and mental health complaints among 8-hour shift workers of petrochemical industries in Iran. Work. https://doi.org/10.3233/WOR-192865

Byrne, B. M. (2016). Structural equation modeling with AMOS: Basic concepts, applications, and programming, second edition. Structural Equation Modeling with AMOS: Basic Concepts, Applications, and Programming, Second Edition (3rd ed.). New York: NY: Routledge. https://doi.org/10.4324/9780203805534

Chin, W. W. (2010). How to write up and report PLS analyses. In Handbook of Partial Least Squares. https://doi.org/10.1007/978-3-540-32827-8_29

Cichy, R. F., Kim, S. H., \& Cha, J. (2009). The relationship between emotional intelligence and contextual performance: Application to automated and vending service industry executives. 
INTERNATIONAL JOURNAL OF ACADEMIC RESEARCH IN BUSINESS AND SOCIAL SCIENCES

Vol. 10, No. 2, Feb, 2020, E-ISSN: 2222-6990 @ 2020 HRMARS

Journal of Human Resources in Hospitality and Tourism, 8(2), 170-183. https://doi.org/10.1080/15332840802269809

Day, A. L., \& Carroll, S. A. (2004). Using an ability-based measure of emotional intelligence to predict individual performance, group performance, and group citizenship behaviours. Personality and Individual Differences. https://doi.org/10.1016/S0191-8869(03)00240-X

Eisenberger, R., Cummings, J., Armeli, S., \& Lynch, P. (1997). Perceived organizational support, discretionary treatment, and job satisfaction. Journal of Applied Psychology. https://doi.org/10.1037/0021-9010.82.5.812

Ferri, P., Guadi, M., Marcheselli, L., Balduzzi, S., Magnani, D., \& Di Lorenzo, R. (2016). The impact of shift work on the psychological and physical health of nurses in a general hospital: A comparison between rotating night shifts and day shifts. Risk Management and Healthcare Policy, 9, 203211. https://doi.org/10.2147/RMHP.S115326

Fitzpatrick, J. M., While, A. E., \& Roberts, J. D. (1999). Shift work and its impact upon nurse performance: Current knowledge and research issues. Journal of Advanced Nursing, 29(1), 1827. https://doi.org/10.1046/j.1365-2648.1999.00861.x

Goleman, D., \& Cherniss, C. (2001). An El-based theory of performance. The emotionally intelligent workplace: How to select for, measure, and improve emotional intelligence in individuals, groups, and organizations, (April).

Hair, J. F., Sarstedt, M., Hopkins, L., \& Kuppelwieser, G. V. (2014). Partial least squares structural equation modeling (PLS-SEM). European Business Review. https://doi.org/10.1108/EBR-102013-0128

Kenny, D. A. (2016). Moderation.

LaDou, J. (1982). Health effects of shift work. The Western Journal of Medicine, 137(6), 525-530.

Loef, B., Van Baarle, D., Van Der Beek, A. J., Beekhof, P. K., Van Kerkhof, L. W., \& Proper, K. I. (2019). The association between exposure to different aspects of shift work and metabolic risk factors in health care workers, and the role of chronotype. PLOS ONE. https://doi.org/10.1371/journal.pone.0211557

Maul, A. (2012). The validity of the Mayer-Salovey-Caruso emotional intelligence test (MSCEIT) as a measure of emotional intelligence. Emotion Review, 4(4), 394-402. https://doi.org/10.1177/1754073912445811

Mc Evoy, J. (2006). An Investigation in to the Effect of Emotional Intelligence (Ei) On Individual Performance at Work and Career Advancement a Management Report submitted in fulfillment of the requirements for award of HIGHER DIPLOMA in PERSONNEL MANAGEMENT, (May).

Mishra, P. (2012). A Study of the Effect of Emotional Intelligence on Academic Achievement of Jaipur Senior Secondary Students. ljert, 34(2), 25-28.

Mohamad, M., \& Jais, J. (2016). Emotional Intelligence and Job Performance: A Study among Malaysian Teachers. Procedia Economics and Finance, 35(October 2015), 674-682. https://doi.org/10.1016/S2212-5671(16)00083-6

Nafukho, F. M. (2009). Emotional intelligence and performance: Need for additional empirical evidence. Advances in Developing Human Resources, 11(6), 671-689. https://doi.org/10.1177/1523422309360838

Rhoades, L., \& Eisenberger, R. (2002). Perceived organizational support: A review of the literature. Journal of Applied Psychology. https://doi.org/10.1037/0021-9010.87.4.698 
INTERNATIONAL JOURNAL OF ACADEMIC RESEARCH IN BUSINESS AND SOCIAL SCIENCES

Vol. 10, No. 2, Feb, 2020, E-ISSN: 2222-6990 @ 2020 HRMARS

Sekaran, U., \& Bougie, R. (2010). Research method for business: A skill building approach, 5th edition. United States: John Wiley \& Sons Inc.

Settoon, R. P., Bennett, N., \& Liden, R. C. (1996). Social exchange in organizations: Perceived organizational support, leader-member exchange, and employee reciprocity. Journal of Applied Psychology. https://doi.org/10.1037/0021-9010.81.3.219

Shooshtarian, Z., Ameli, F., \& Aminilari, M. (2013). The Effect of Labor's Emotional Intelligence on Their Job Satisfaction, Job Performance and Commitment. Iranian Journal of Management Studies (IJMS), 6(1), 29-45. https://doi.org/10.5539/ijbm.v11n2p69

Urbach, N., \& Ahlemann, F. (2010). Structural equation modeling in information systems research using partial least squares. Journal of Information Technology Theory and Application (JITTA). https://doi.org/10.1037/0021-9010.90.4.710

Welikala, \& Dayarathna. (2015). [04] The Impact of Emotional Intelligence on Employee Job Performance: An Empirical Study base on the Commercial Banks in Central Province. HRM Scintilla Human Resource Management Journal, 03(01), 33-41. https://doi.org/10.31357/hrmj.v3i1.2933

Wong, C. S., \& Law, K. S. (2002). The effects of leader and follower emotional intelligence on performance and attitude: An exploratory study. Leadership Quarterly. https://doi.org/10.1016/S1048-9843(02)00099-1 